\title{
Functional Requirements for Inter-enterprise Intranet Services
}

\author{
A.S. Kazi and M. Hannus \\ VTT Building Technology, Finland \\ Em:Sami.Kazi@vtt.fi
}

Keywords Inter-enterprise Communications, Intranet, Distributed Engineering, IMSGLOBEMEN

\begin{abstract}
A core requirement for inter-enterprise collaboration in a virtual enterprise (VE) is the availability of an inter-enterprise Intranet service that facilitates the seamless flow of data and information between the different actors involved in addition to fostering an environment for collaboration. This paper is based on explorations and findings of trying to find/develop an inter-enterprise Intranet service for the participants of a virtual enterprise. Some required functionalities/support that were identified include: concurrent engineering, suitability to project business conditions, open system architecture, electronic document management, product structure/configuration management, access control, redlining/mark-up, groupwork support, user profiling, version and revision management, workflow management, distributed databases, application integration, and application launching. The paper concludes by illustrating an envisioned system architecture for inter-enterprise intranet services.
\end{abstract}

\section{INTRODUCTION}

An evolving and currently under heavy research operational paradigm is through the formation of a virtual enterprise. This typically entails the efforts from different organisations participating together to resolve a unique problem or deliver a unique product. While it may be argued at length that this is the operational norm of many industries such as manufacturing, shipbuilding, construction, etc., a formal methodology for the process doesn't exist. Moreover, the concern lies more on the way that information is shared than others. With the participants of each organisation potentially using different proprietary systems, the sharing of information can become a 
bottleneck to the effectiveness of the virtual enterprise (VE). It may be argued that a common IT environment in terms of an application software platform should be enforced, this is not very practical when the reality that each participant may be involved in different virtual enterprises at a given time and adherence to a VE specific software application platform would seem uncalled for. The simple question then is, "How to share information between heterogeneous systems?"

While an exploration of the mechanism and alternatives for sharing information between heterogeneous systems is beyond the scope of this paper, it should suffice to mention that this is possible through compliance with information exchange standards (e.g. ISO-STEP).

The focus of this paper is on identifying possible solutions and implementation mechanisms for intranet services to enable inter-enterprise communications in a virtual enterprise setting. Core findings are related to early explorations within the IMS GLOBEMEN project, and the authors' experiences in several EU projects, especially CONCUR, PROCURE, and ToCEE.

\section{INTER-ENTERPRISE COMMUNICATION}

Initially, inter-enterprise communications in a virtual enterprise setting were based on document exchange between individual participants. This not only led to data/information redundancy, but a lack of control as to which information exists where and as to who is the owner of the information. Each participant either had to have the same application software installed as that of the sender's, or to alternatively use some document "viewing" tools. Furthermore, there was no central location where the information was stored.

Current intranet environments for VE settings are based on the concept of a shared information repository where project related data and information is stored. This resolves most of the issues raised in the previous form (see above) of inter-enterprise communications. One pitfall in this approach is that it is centred on the individuals participating within the VE without concern for their organisations, which in fact form the contractual basis for the VE. Furthermore, an individual/organisation may only wish to release a certain "amount" of information to the VE consortium whilst keeping the rest "internal". Last but not least, from a legal perspective, any document released to the "central repository" should imply endorsement from the organisation to which it belongs.

The road to the future is through the communication of organisation dependent intranets to the "central repository" and VE intranet. This would 
typically entail the transfer of "information packages" on a periodic basis from a participating organisation's internal system to the VE intranet. At the same time, this ensures compliance with legal contracts as in this form the information is coming from an organisation and not an individual. The two systems, organisation specific and VE would typically communicate through "interfaces" thereby eliminating/minimising the need for "compliance" with each other.
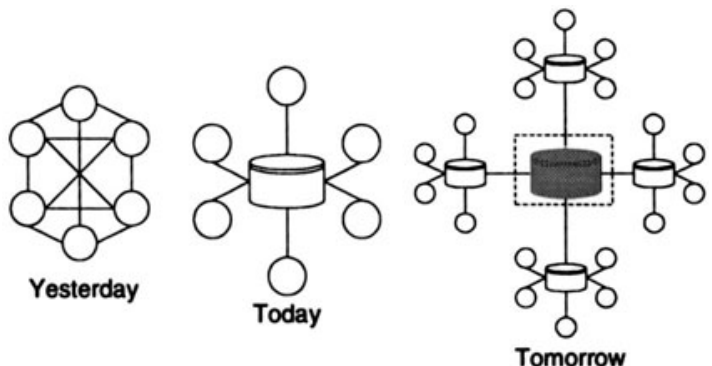

Figure 1 Inter-enterprise communication forms

We now proceed to presenting a summary of some functional requirements and their priorities within a VE setting. More information related to issues and needs resolution that led to the identification of the functionalities has been published elsewhere [1].

\section{FUNCTIONAL REQUIREMENTS AND PRIORITIES}

Table 1 summarises the perceived required functionalities of a VE intranet. Functionality priorities are identified from the perspective of interenterprise communication. Hence those that may be important at an organisational level alone are assigned a lower priority.

\section{ENVISIONED SYSTEM ARCHITECTURE}

One of the focus points of the IMS GLOBEMEN project [2] is related to the identification of requirements and specifications for a distributed engineering environment. This environment will in a way serve as a platform for inter-enterprise communications within a VE setting. In this section, we present the basic system requirements and illustrate a possible system architecture for the same.

Within dynamic VE conditions it is almost mandatory for interenterprise communication that a commonly accessible and usable 
communication infrastructure exists. Furthermore, each participant organisation would have its own legacy systems for internal use. For external communications with other members of the VE, the most feasible norm would be to communicate based on available standards. Organisation specific intranets and legacy tools could communicate with the VE intranet through interfaces enabling data/information mapping between the two intranets (Figure 2).

Table 1 Functional requirements and priorities for $V E$ intranet services.

\begin{tabular}{|c|c|c|}
\hline $\begin{array}{l}\text { Function } \\
\text {-ality }\end{array}$ & Explanation & Priority \\
\hline $\begin{array}{l}\text { Concur- } \\
\text { rent } \\
\text { Engin- } \\
\text { eering }\end{array}$ & $\begin{array}{l}\text { As part of the business process, information needs to be captured, } \\
\text { (explicitly an implicitly), shared and controlled. Sources of } \\
\text { information include: verbal instructions and information, } \\
\text { applications, management tools, planning network analyses, } \\
\text { reference specifications, computer model analysis, spreadsheets, } \\
\text { drawings and layouts, three dimensional CAD models, sketches, } \\
\text { calculations and supporting data, detailed designs, multi-media, } \\
\text { etc. All this constitutes the complete project/product definition and } \\
\text { needs to be captured and controlled. }\end{array}$ & High \\
\hline $\begin{array}{l}\text { Suit- } \\
\text { ability to } \\
\text { project }\end{array}$ & $\begin{array}{l}\text { Internet-connectivity is very important. Accessibility via normal } \\
\text { WWW browser (Netscape or IE). Ease of use. Quick set-up for } \\
\text { new projects. Feasible licensing conditions for project conditions } \\
\text { considering temporary use by several legal units. Back up of all } \\
\text { project data. Usability of data after end/termination of VE (e.g. on } \\
\text { a CD without reliance on a particular software) }\end{array}$ & High \\
\hline $\begin{array}{l}\text { Open } \\
\text { system } \\
\text { archit- } \\
\text { ecture }\end{array}$ & $\begin{array}{l}\text { Ability to connect different kinds of company specific applications } \\
\text { and working environments. API for application integration. } \\
\text { Interfaces must be based on standards: STEP / IFC, CORBA, PDM } \\
\text { schema, Excel/Access etc. }\end{array}$ & High \\
\hline $\begin{array}{l}\text { Elect- } \\
\text { ronic } \\
\text { docu- } \\
\text { ment } \\
\text { manage } \\
\text { ment }\end{array}$ & $\begin{array}{l}\text { Procedures for document release, change, update and replacement. } \\
\text { Publishing of distributed project information making it available to } \\
\text { participants. Notify users about changes. Keep track on document } \\
\text { dependencies. Version management. Document life-cycle } \\
\text { management: support controlled change of documents from draft, } \\
\text { working to release, change etc. Search mechanism based on } \\
\text { attributes of meta-data and also on contents. Browser view support } \\
\text { for many common data formats: CAD-files, IFC \& STEP, MS } \\
\text { Office documents and databases, HTML, VRML, SGML, XML, } \\
\text { etc. }\end{array}$ & High \\
\hline $\begin{array}{l}\text { Access } \\
\text { control }\end{array}$ & $\begin{array}{l}\text { Manage access rights of users/roles in different projects/VEs. } \\
\text { Maintain log (history) of all transactions. Assure authenticity of } \\
\text { documents (objects): for legal reasons the originality of a released } \\
\text { document (object) as submitted by the author must be guaranteed. } \\
\text { Support for role specific views. Templates for fast configuring of } \\
\text { the system. Support for IPR protection. }\end{array}$ & High \\
\hline
\end{tabular}




\begin{tabular}{|c|c|c|}
\hline $\begin{array}{l}\text { Product } \\
\text { structure/ } \\
\text { config- } \\
\text { uration } \\
\text { manage } \\
\text { ment }\end{array}$ & $\begin{array}{l}\text { Manage product structure (assemblies, subassemblies, components, } \\
\text { relationships), related documents and data. Support information } \\
\text { navigation according to product structure. Change and manage } \\
\text { product structure with consequences to documentation, production } \\
\text { planning and bills of materials/quantities (BOM/BOQ). Provide } \\
\text { alternative and user specific breakdown structures (views). Manage } \\
\text { alternative product configurations (designs). Search mechanism } \\
\text { based on meta-data, attributes and relationships of objects. }\end{array}$ & High \\
\hline $\begin{array}{l}\text { Red- } \\
\text { lining/ } \\
\text { mark-up }\end{array}$ & $\begin{array}{l}\text { Allow users to view different types (doc, } x l s, \text { dwg, etc.) of } \\
\text { documents (objects) and make comments to the subject just } \\
\text { through marking / redlining. }\end{array}$ & $\begin{array}{l}\text { Mediu } \\
\mathrm{m}\end{array}$ \\
\hline $\begin{array}{l}\text { Group- } \\
\text { work } \\
\text { support }\end{array}$ & $\begin{array}{l}\text { Enable distributed team of persons to collaborate as if they were } \\
\text { located in a common office: group-calendars, email, video / } \\
\text { desktop conferencing, discussion groups, bulletin boards, shared } \\
\text { document archives, common IT applications etc. }\end{array}$ & $\begin{array}{l}\text { Mediu } \\
\mathrm{m}\end{array}$ \\
\hline $\begin{array}{l}\text { User } \\
\text { profiling }\end{array}$ & $\begin{array}{l}\text { Allow functionalities to be adjusted to the capabilities and needs of } \\
\text { different users. Differentiate "user" and "role": access control is } \\
\text { role-specific while profiling is user-specific. }\end{array}$ & Low \\
\hline $\begin{array}{l}\text { Version } \\
\text { manage- } \\
\text { ment }\end{array}$ & $\begin{array}{l}\text { Manage new, parallel, alternative versions of documents (objects). } \\
\text { Maintain change history. For practical reasons old versions may } \\
\text { not need to accessible on-line. Back-ups should be stored. }\end{array}$ & Low \\
\hline $\begin{array}{l}\text { Work- } \\
\text { flow } \\
\text { manage- } \\
\text { ment }\end{array}$ & $\begin{array}{l}\text { Control transfer of documents (objects) between individuals in a } \\
\text { shared working process for review, approval, change request etc. } \\
\text { Support informal \& formal processes. Highlight pending tasks to } \\
\text { users. }\end{array}$ & Low \\
\hline $\begin{array}{l}\text { Distribut } \\
\text { ed } \\
\text { database }\end{array}$ & $\begin{array}{l}\text { Managed interconnected data storages residing on different } \\
\text { servers. Partial replication of selected data. The architecture should } \\
\text { allow non-continuous connection between servers. }\end{array}$ & Low \\
\hline $\begin{array}{l}\text { App. } \\
\text { integrat- } \\
\text { ion }\end{array}$ & $\begin{array}{l}\text { Provide tools for information sharing / data exchange between } \\
\text { various IT applications. Typical means would be standards based } \\
\text { interfaces, an object database and an API. }\end{array}$ & Low \\
\hline $\begin{array}{l}\text { App. } \\
\text { launch }\end{array}$ & $\begin{array}{l}\text { Allow end user to launch various applications on active documents } \\
\text { / objects. }\end{array}$ & Low \\
\hline
\end{tabular}

Once the basic framework is established, it may be wise to explore the environment in more detail. Within the GLOBEMEN project, the work related to distributed engineering in a VE setting noted that an interenterprise intranet should be able to manage documents, product models, and processes/workflows. Therefore, in addition to the main functionalities identified in previous sections, there should be a document manager, product model manager, and process data manager. These basically provide different perceptual views to the data/information that is stored and shared trough the inter-enterprise intranet. The envisioned system architecture is shown in figure 3 followed by a brief explanation of its components.

Once the basic framework is established, it may be wise to explore the environment in more detail. Within the GLOBEMEN project, the work 
related to distributed engineering in a VE setting noted that an interenterprise intranet should be able to manage documents, product models, and processes/workflows [3]. Therefore, in addition to the main functionalities identified in previous sections, there should be a document manager, product model manager, and process data manager. These basically provide different perceptual views to the data/information that is stored and shared trough the inter-enterprise intranet. The envisioned system architecture is shown in figure 3 followed by a brief explanation of its components.
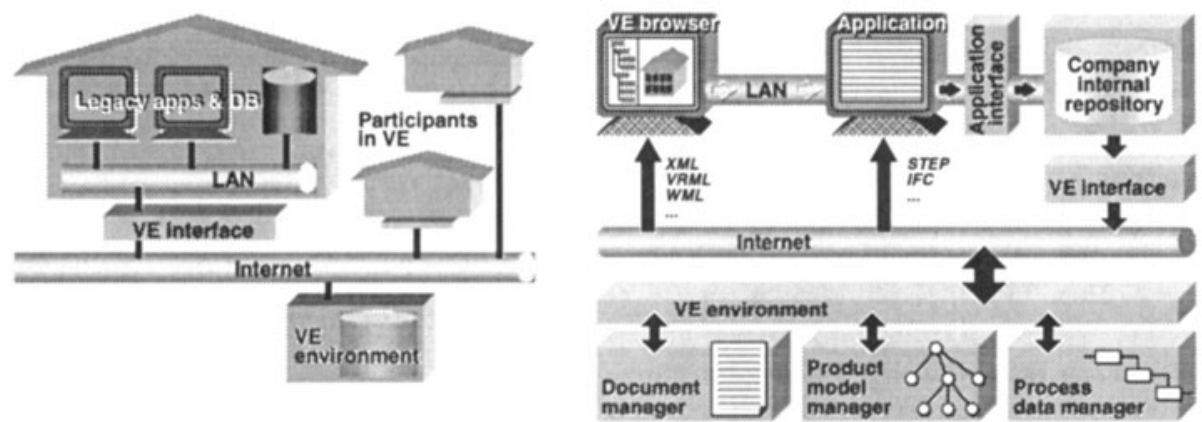

Figure 3 Envisioned system architecture for inter-enterprise communications.

As is evident from figure 3 , the envisioned system architecture is quite generic in nature. The main components are:

- VE environment: A common data repository and sharing environment for organisation participating in the VE. It should provide support for distributed groupwork and sharing of information based on available (or agreed upon) standards. Different modules for the management and control of documents, products, and product models should be provided.

- VE interface: An organisation specific module, which provides a means for information exchange and communication between the organisation specific systems and the VE environment (intranet). The VE interface would be the communication bridge between the two systems and the control agent for the transfer of released information to the VE environment.

- VE browser: A tool that will enable users to search, view, and retrieve data from the VE environment. Note that transfers of information to the $V E$ environment are in the form of information releases by a particular organisation and only allowed through the VE interface.

Other system components relate to the internal system and tools of each participant organisation: 
- Applications: Tools that an organisation uses internally for performing and managing its core business.

- Application Interfaces: Services that enable applications to access the internal repositories of the organisation so users are able to store and retrieve data in line with the workflow of the organisation.

- Organisation internal repository: Organisation specific information storage and management system.

\section{CONCLUSION}

An envisioned system architecture was presented that focuses on the control and management of documents, product models, and processes/workflows. The system uses the Internet as a communications infrastructure and VE interfaces to exchange data based on standards between organisation specific systems and the VE environment.

Developments in GLOBEMEN to support inter-enterprise communications and information sharing for distributed engineering will include: integration of product model management with current document management technology, VE specific functionality to GroupWare tools, product model repositories with model merging and partial model extraction capabilities, VRML based user interface to access product model objects and related documents, and XML based product model access over the web.

More findings and developments will be reported and published as they become available during the course of the GLOBEMEN project (January 2000 - January 2003).

\section{REFERENCES}

[1] Hannus M., Aarni V. (1999). Requirements for Concurrent Engineering Environment in Concur Project, Concurrent Engineering in Construction: Challenges for the New Millennium, CIB publication 236, 25-27 August, Espoo, Finland, 99-110

[2] IMS GLOBEMEN web site: http://globemen.vtt.fi

[3] Hannus M., Kazi A.S. (2000) Requirements for Distributed Engineering, Product and Process Modelling in Building and Construction (ECPPM 2000), 25-27 September, Lisbon, Portugal, 41-48 